\title{
Three Phases of TRH-Induced Facilitation of Exocytosis by Single Lactotrophs
}

\author{
Alla F. Fomina a and Edwin S. Levitan \\ Department of Pharmacology, University of Pittsburgh, Pittsburgh, Pennsylvania 15261
}

\begin{abstract}
Membrane capacitance measurements were used to study neuropeptide modulation of exocytosis by perforated patch clamped rat lactotrophs. We report that depolarizing voltage-clamp pulses evoke exocytosis that is steeply dependent on $\mathrm{Ca}^{2+}$ influx through voltage-gated $\mathrm{Ca}^{2+}$ channels. Furthermore, we find that the neuropeptide TRH (thyrotropin-releasing hormone) acts in three phases to promote exocytosis. First, TRH transiently (within $\sim 0.5 \mathrm{~min}$ ) triggers depolarization- and extracellular $\mathrm{Ca}^{2+}$-independent exocytosis. Second, within 3 min of application, TRH facilitates depolarization-evoked exocytosis while inhibiting voltagegated $\mathrm{Ca}^{2}$ current. Finally, after $8 \mathrm{~min}$, TRH further enhances depolarization-evoked exocytosis by increasing high-voltage-activated (HVA) $\mathrm{Ca}^{2+}$ channel current. Activation of protein kinase C (PKC) with a phorbol ester also stimulates depolarization-evoked exocytosis by increasing $\mathrm{Ca}^{2+}$ current. Therefore, PKC can only account for the last effect of TRH. Thus, a single neuromodulator may employ several temporally distinct mechanisms to stimulate peptide secretion.
\end{abstract}

[Key words: exocytosis, calcium channel, neuropeptide, prolactin, protein kinase $C$, pituitary]

Many neuromodulators regulate peptide secretion by neurons and endocrine cells. Because the effects of secreted peptides are typically slow, it has not been possible to study neuromodulation of peptidergic transmission in the nervous system with quantal analysis. Rather, secretion of ncuropeptides and peptide hormones has usually been assayed biochemically, with the use of the reverse hemolytic plaque assay, or has been inferred from slow synaptic responses or other bioassays. The limited time resolution of these methods, however, has hindered direct linkage of neuromodulator effects on production of second messengers, membrane potential and $\mathrm{Ca}^{2+}$ channel activity to changes in peptide secretion. Recently, recordings of membrane capacitance changes have allowed rapid and high resolution measurements of exocytotic activity from a variety of peptidergic cells including melanotrophs (Thomas et al., 1990; Okano et al., 1993), pancreatic $\beta$ cells (Ammala et al., 1993a,b), gonadotrophs

\footnotetext{
Received Dec. 16, 1994; revised Feb. 8, 1995; accepted Feb. 10, 1995.

We thank Drs. J. P. Horn and W. C. DeGroat for reading an earlier version of the manuscript. Antisera were provided by the National Hormone and Pituitary Program (University of Maryland School of Medicine) and NIDDK. This research was supported by a Klingenstein Fellowship in the Neurosciences, an American Heart Association (PA affiliate) Grant-in-aid, and NIH Grant NS29804 to E.S.L.

Correspondence should be addressed to Edwin S. Levitan at the above address.

aPermanent address: Bogomoletz Institute of Physiology, Kiev, Ukraine.

Copyright (C) 1995 Society for Neuroscience $0270-6474 / 95 / 154982-10 \$ 05.00 / 0$
}

(Tse et al., 1993), neurohypophysis terminals (Lim et al., 1990), and lactotrophs (Sikdar et al., 1989, 1990; Zorec et al., 1991). Those studies have examined the influence of intracellular $\mathrm{Ca}^{2+}$, G-proteins, and cAMP on exocytotic activity. In most cases, conventional whole-cell recording was used which, by dialyzing the cytoplasm, can alter normal control of exocytosis (Augustine and Neher, 1992; Ammala et al., 1993b). Furthermore, few experiments have examined the effects of neuromodulators on exocytosis. Therefore, the full complexity of control of peptide secretion by neuromodulators may have not been revealed by previous studies.

We chose to study the action of the neuropeptide thyrotropinreleasing hormone (TRH) on metabolically intact peptidergic cells. TRII and its receptor are widcly distributcd throughout the CNS (Faglia and Persani, 1991; Wu et al., 1992; Satoh et al., 1993). This neuropeptide affects hehavior, augments long-term potentiation, and stimulates catecholamine secretion in the brain (Faglia and Persani, 1991; Ishihara et al., 1991, 1992). In addition, TRH secreted by hypothalamic neurons promotes secretion of the peptide hormone prolactin by pituitary lactotrophs, which in turn affects the reproductive and immune systems. Work with clonal pituitary cells suggests that TRH-induced prolactin secretion occurs in two phascs. First, TRH initially crokcs a transient burst of secretion that is associated with release of intracellular $\mathrm{Ca}^{2+}$. Then TRH evokes a second sustained phase of secretion that requires $\mathrm{Ca}^{2+}$ influx through voltage-gated $\mathrm{Ca}^{2+}$ channels and is associated with increased action potential activity and activation of protein kinase C (PKC) (Mason et al., 1988, 1989; Gershengorn, 1989; Iijima et al., 1990). PKC activators also stimulate prolactin secretion from normal lactotrophs (Negro-Vilar and Lapetina, 1985) via an unknown mechanism. Howcver, in normal pituitary cells, $\mathrm{Ca}^{2+}$ influx through voltagegated $\mathrm{Ca}^{2+}$ channels plays a major role in both phases of TRHinduced prolactin secretion (Sato et al., 1992). To further explore the role of voltage-gated $\mathrm{Ca}^{2+}$ channels in TRH-induced secretion, we have used the perforated patch technique, which leaves cells metabolically intact, to examine the action of TRH on lactotroph voltage-gated $\mathrm{Ca}^{2+}$ currents and exocytotic activity.

Here we report that exocytosis measured as an increase in membrane capacitance is steeply dependent on $\mathrm{Ca}^{2+}$ influx through voltagc-gated $\mathrm{Ca}^{2+}$ channels. Furthermore, we show that TRH acts in three phases to promote exocytosis by voltageclamped rat lactotrophs. Within the first minute of application, the neuropeptide transiently evokes exocytosis that is independent of $\mathrm{Ca}^{2+}$ influx and membrane depolarization. During the first few minutes, TRH also facilitates depolarization-evoked exocytosis while inhibiting $\mathrm{Ca}^{2+}$ influx through voltage-gated $\mathrm{Ca}^{2+}$ channels. Finally, after $\sim 8 \mathrm{~min}$, TRH further stimulates 
depolarization-evoked exocytosis by increasing voltage-gated $\mathrm{Ca}^{2+}$ channel activity. Only this latter effect appears to be mediated by activation of protein kinase $\mathrm{C}$. Thus, a single neuromodulator can act via several temporally distinct mechanisms to promote peptide secretion.

\section{Materlals and Methods}

Cell preparation and identification. Anterior pituitary glands were dissected from retired breeder female Sprague-Dawley rats. Cells were dissociated by incubations at $37^{\circ} \mathrm{C}$ first in a Mg-Ca-free buffer $(125 \mathrm{mM}$ $\mathrm{NaCl}, 5 \mathrm{~mm} \mathrm{KCl}, 1.2 \mathrm{mM} \mathrm{KH}_{2} \mathrm{PO}_{4}, 25 \mathrm{~mm} \mathrm{NaHCO}, 15 \mathrm{~mm}$ glucose, pH 7.4) containing $10 \mathrm{mg} / \mathrm{ml}$ bovine serum albumin (BSA, fraction $\mathrm{V}$, Sigma) with $1 \mathrm{mg} / \mathrm{ml}$ trypsin (type III, Sigma) for $30 \mathrm{~min}$, and then in Mg-Ca-supplemented buffer (the same buffer above supplemented with $1 \mathrm{mM} \mathrm{MgSO}_{4}$ and $1.8 \mathrm{mM} \mathrm{CaCl}_{2}$ ) with $1 \mathrm{mg} / \mathrm{ml}$ Viokase (Pancreatin, Sigma) for $90 \mathrm{~min}$. Cells were then triturated using Pasteur pipettes. The cell suspension harvested from one rat was centrifuged through 4 $\mathrm{ml}$ layer of Mg-Ca-containing buffer supplemented with $200 \mathrm{mg} / \mathrm{ml}$ BSA at $500 \times g$ for 5 min. The pellet was resuspended in Ham's F-10 culture medium supplemented with $2.5 \%$ fetal bovine serum and $12.5 \%$ horse serum (GIBCO) to $1-2 \times 10^{4}$ cells $/ \mathrm{ml} ; 2 \mathrm{ml}$ of the cell suspension were placed into $35 \mathrm{~mm}$ plastic dishes with fire-flamed glass gridded coverslip (Eppendorf) on the bottom and cultured for up to $7 \mathrm{~d}$ in a $5 \%$ $\mathrm{CO}_{2}$ incubator at $37^{\circ} \mathrm{C}$. By immunoffuorescence (see below), $50-80 \%$ cells isolated by this method were identified as immunoreactive for prolactin.

Immunocytochemical labeling. For identification of the PRL-containing cells we followed a procedure described previously (St. John et al., 1986). Briefly, for immunoffuorescent surface labeling of living cells, the culture media was removed and washed once with phosphate buffer (PBS, pH 7.4) and then kept for $1 \mathrm{hr}$ in buffer solution B (140 mm $\mathrm{NaCl}, 5 \mathrm{~mm} \mathrm{KCl}, 20 \mathrm{~mm}$ NaHEPES, $4 \mathrm{mg} / \mathrm{ml} \mathrm{BSA}, \mathrm{pH}$ 7.4) with diluted $(1: 1000)$ primary anti-rat prolactin antibody (anti-RPRL-IC-4, rabbit, NIDDK-NIH) at room temperature. The cells were rinsed three times with buffer solution $\mathrm{A}$, then incubated at room temperature in fluorescein-conjugated secondary antibody (anti-rabbit IgG FITC-conjugate, Sigma) used at final concentration 1:200 for $60 \mathrm{~min}$. After this incubation, cells were rinsed and the coverslip was transferred into experimental chamber on an Olympus IMT-2 fluorescent microscope.

To assay intracellular hormone content after experiments, the recording solution was replaced with fixative $[4 \%(\mathrm{w} / \mathrm{v})$ paraformaldehyde in PBS, pH 7.4] and incubated for $30 \mathrm{~min}$ at $4^{\circ} \mathrm{C}$. After fixation, cells were rinsed with PBS, then permeabilized by treatment with Triton X-100 $(0.25 \%$ in buffer solution $\mathrm{B})$ for $5 \mathrm{~min}$ and rinsed again. Labeling was performed with 1:1000 dilutions of primary antibodies against rat PRL and growth hormone (NIDDK-anti-rGH-IC-1, \#AFP411S, monkey, NIDDK-NIH). Primary antibodies were applied for $1 \mathrm{hr}$ at $4^{\circ} \mathrm{C}$. Cells were rinsed three times with buffer solution and then incubated for 60 $\mathrm{min}$ in fluorescein anti-monkey IgG FITC-conjugate (Sigma) and then rhodamine-conjugated anti-rabbit IgG TRITC-conjugate (Sigma) secondary antibodies used at final dilutions of 1:1000. Cells were rinsed with buffer solution before observation.

Electrical recording. Cells were voltage clamped in whole-cell amphotericin-perforated patch recording mode (Rae et al., 1991) using List EPC-9 patch-clamp amplifier with ATARI computer and E9Screen (3.0) software (HEKA electronic) to control the amplifier and acquire data. Bath solutions were (1) for $\mathrm{Ca}^{2+}$ current measurements, $60 \mathrm{mM} \mathrm{NaCl}$, $90 \mathrm{~mm} \mathrm{NaOH}, 20 \mathrm{~mm}$ tetraethylammonium hydroxide (TEA.OH), $5 \mathrm{mM}$ $\mathrm{Ca}(\mathrm{OH})_{2}, 1 \mathrm{~mm} \mathrm{MgCl}_{2}, 10 \mathrm{~mm}$ NaHEPES, $10 \mathrm{~mm}$ glucose, $1 \mu \mathrm{M}$ tetrodotoxin [pH was adjusted to 7.4 with methanesulfonic acid (Fluka)] (in some experiments $\left[\mathrm{Ca}^{2+}\right]$ was varied between 2 and $10 \mathrm{~mm}$ ); (2) for $\mathrm{Ba}^{2+}$ current measurements, $60 \mathrm{~mm} \mathrm{NaCl}, 90 \mathrm{~mm} \mathrm{NaOH}, 20 \mathrm{~mm}$ TEA.OH, $5 \mathrm{~mm} \mathrm{Ba}(\mathrm{OH})_{2}, 1 \mathrm{~mm} \mathrm{MgCl}_{2}, 10 \mathrm{~mm}$ NaHEPES, $10 \mathrm{~mm}$ glucose, $1 \mu \mathrm{M}$ tetrodotoxin ( $\mathrm{pH}$ adjusted to 7.4 with methanesulfonic acid); or (3) $150 \mathrm{mM} \mathrm{NaCl}, 2 \mathrm{~mm} \mathrm{CaCl}, 1 \mathrm{~mm} \mathrm{MgCl}$, $2.5 \mathrm{mM} \mathrm{KOII,}$ $10 \mathrm{~mm}$ NaHEPES, $10 \mathrm{~mm}$ glucose (pH adjusted to 7.4 with methanesulfonic acid). Pipette solutions were (1) for $\mathrm{Ca}^{2+}$ and $\mathrm{Ba}^{2+}$ current

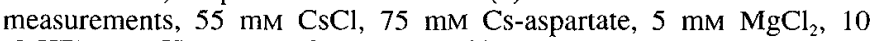
NaHEPES, pH 7.4.; or (2) $55 \mathrm{mM} \mathrm{KCl,} 75 \mathrm{mM} \mathrm{K}_{2} \mathrm{SO}_{4}, 5 \mathrm{mM} \mathrm{MgCl}_{2}$, $10 \mathrm{~mm}$ NaHEPES, pH 7.4. Osmolarity of bath solutions was $310-320$ mOsm and internal solutions $290-300 \mathrm{mOsm}$. A stock solution of amphotericin B ( $4 \mathrm{mg} / 50 \mu \mathrm{l}$ DMSO) was prepared before each experiment; $4 \mu \mathrm{l}$ of stock solution was dissolved by sonication in pipette solution and stored in the dark for no longer then $1 \mathrm{hr}$. Resistance of pipettes filled with these solutions ranged between 2.8-4.0 M $\Omega$ Access resistance $\left(R_{a}\right)$ stabilized at $21.1 \pm 0.6 \mathrm{M} \Omega(N=94)$ after $5-10 \mathrm{~min}$ of perforation and did not changed significantly during experiment.

Membrane capacitance was measured with the time-domain technique (Lindau and Neher, 1988) using the EPC-9 capacitance tracking feature. Capacitance measurements were obtained at $\sim 1 \mathrm{~Hz}$. Capacitance, current, voltage, and $R_{u}$ data were recorded on PCM videocassette recorders and then displayed with a four-channel digital chart recorder (WR7700, Western Graphtec, Inc.). Membrane currents were acquired and stored on hard disk along with $p / 4$ leak subtraction records. To ensure that capacitance responses were consistent (i.e., to prevent frequency dependent facilitation or depression), cells were stimulated once every 1-3 min. Except when indicated otherwise, experiments were done at $32^{\circ} \mathrm{C}$. All measurements are given \pm SEM.

\section{Results}

\section{Depolarization-evoked $\mathrm{Ca}^{2+}$ influx triggers rapid exocytosis and slow endocytosis}

Exocytotic secretion was monitored as a change in membrane capacitance $\left(\Delta C_{m}\right)$ in single voltage clamped rat lactotrophs. The average cell membrane capacitance at the beginning of experiments was $6.6 \pm 0.3 \mathrm{pF}$ (mean $\pm \mathrm{SEM}, N=94$ ). However, capacitance could be increased with voltage steps: $50-1000$ msec depolarizations from $-70 \mathrm{mV}$ to $+10 \mathrm{mV}$ evoked increases in membrane capacitance that were complete within the time resolution of our measurements (i.e., within $1 \mathrm{sec}$ ) (Fig. 1). These capacilance increases were not correlated with changes in access conductance or holding current. Furthermore, the capacitance responses were very temperature dependent: at room temperature, depolarizations less than $500 \mathrm{msec}$ never evoked capacitance changes $(n=55)$, while at $32^{\circ} \mathrm{C}, C_{m}$ increased more than $50 \mathrm{fF}$ in response to $100 \mathrm{msec}$ depolarization in 28 of 39 cells. Hence, depolarization to $+10 \mathrm{mV}$ triggers rapid exocytosis in a temperature dependent manner.

The exocytosis evoked by depolarization to $+10 \mathrm{mV}$ was associated with $\mathrm{Ca}^{2+}$ influx through the voltage gated $\mathrm{Ca}^{2+}$ channels (Fig. 1A). In contrast, depolarizing pulses to $+60 \mathrm{mV}$ elicited outward current and were not followed by capacitance changes. The dependence of depolarization-induced exocytosis on $\mathrm{Ca}^{2+}$ entry was further confirmed by demonstrating that the exocytotic response to depolarization was proportional to the bath $\mathrm{Ca}^{2+}$ concentration. Elevating the extracellular $\mathrm{Ca}^{2+}$ concentration increased voltage-gated $\mathrm{Ca}^{2+}$ entry and exocytosis (Fig. $1 B)(N=3)$, while replacing bath $\mathrm{Ca}^{2+}$ with $\mathrm{Co}^{2+} \mathrm{com}-$ pletely and reversibly abolished depolarization-evoked exocytosis $(N=5)$ (Fig. 2). Thus, $\mathrm{Ca}^{2+}$ influx through voltage-gated $\mathrm{Ca}^{2+}$ channels can trigger rapid exocytosis by single lactotrophs.

Capacitance recordings can also be used to monitor endocytosis. We found that after voltage clamping the membrane potential to $-70 \mathrm{mV}$ with the perforated patch-clamp method, membrane capacitance slowly declined $\left(\Delta C_{n} / \Delta t=-55.9 \pm 4.7\right.$ $\mathrm{fF} / \mathrm{min}, N=22$ ). Under our standard conditions, depolarizations that triggered exocytosis did not significantly affect the rate of the gradual decrease in membrane capacitance $(-50.4 \pm 3.9 \mathrm{fF} /$ $\min , N=41$ ). Likewise, basal endocytosis did not change in response to depolarizations in the presence of $\mathrm{Co}^{2+}$ (Fig. 2). However, when voltage-gated $\mathrm{Ca}^{2+}$ current was increased by elevating bath $\mathrm{Ca}^{2+}$ to concentrations $>5 \mathrm{~mm}$, endocytosis became more rapid ( $\Gamma i g .1 B$ ); for example, raising bath $\left[\mathrm{Ca}^{2+}\right]$ from 2 $\mathrm{mM}$ to $6 \mathrm{~mm}$ increased the rate of postdepolarization endocytosis from $-62.7 \pm 19.1 \mathrm{fF} / \mathrm{min}$ to $-133 \pm 41.6 \mathrm{fF} / \mathrm{min}(N=3)$ Even after stimulation, endocytosis was far slower than depolarization-evoked exocytosis. Thus, the detected changes in the rate of endocytosis did not significantly affect our measurements 
A

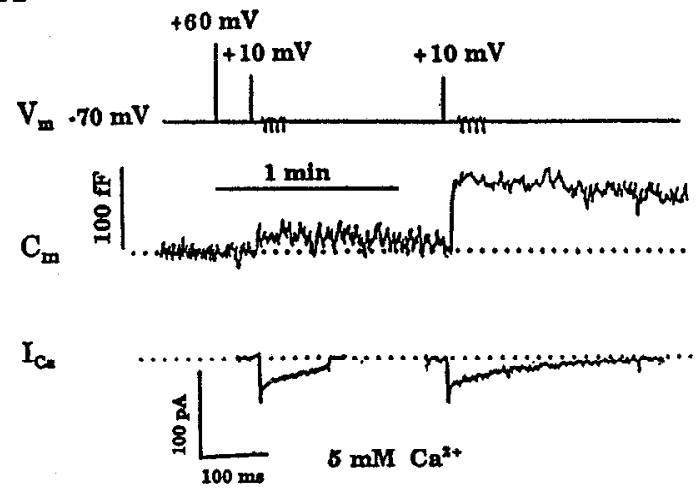

B

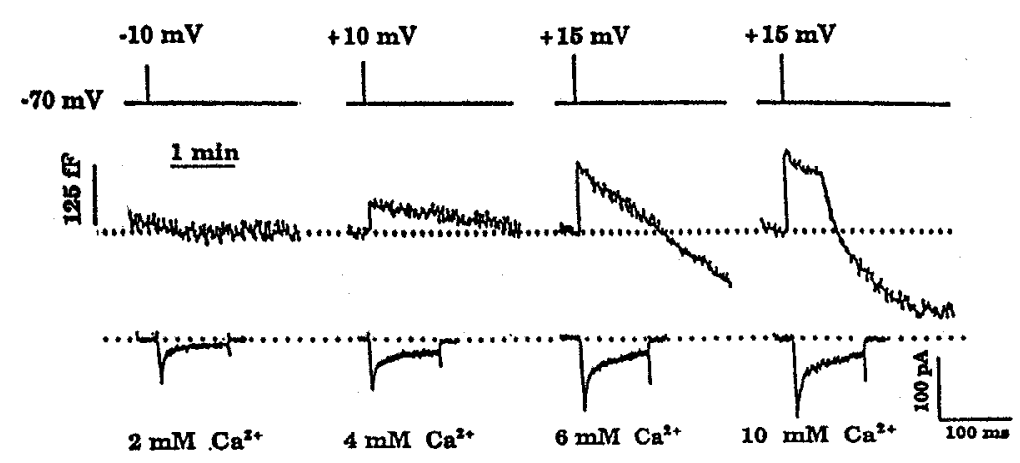

Figure 1. Voltage-gated $\mathrm{Ca}^{2+}$ currents and exocytotic activity measured from single lactotrophs. $\mathrm{Ca}^{2+}$ current $\left(I_{\mathrm{Ca}}\right)$, capacitance $\left(C_{m}\right)$, and voltage $\left(V_{m}\right)$ are shown. $A$, Depolarization from $-70 \mathrm{mV}$ to $+60 \mathrm{mV}$ for $250 \mathrm{msec}$ induced outward current (not shown) which was not associated with capacitance changes. Depolarization to $+10 \mathrm{mV}$ for $100 \mathrm{msec}$ and $250 \mathrm{msec}$ induced inward $\mathrm{Ca}^{2+}$ currents and $C_{m}$ increases. Hyperpolarizing pulses for leak subtraction did not affect $C_{m}$. Initial cellular capacitance and access resistance were $5.23 \mathrm{pF}$ and $16.7 \mathrm{M} \Omega$ respectively. $B$, Elcvating bath $\left[\mathrm{Ca}^{2+}\right]$ from 2 to $10 \mathrm{~mm}$ increased voltage-gated $\mathrm{Ca}^{2+}$ current and depolarization-evoked exocytosis and endocytosis. Because of the changes in bath $\left[\mathrm{Ca}^{2+}\right]$, different voltage steps were used to evoked maximal $\mathrm{Ca}^{2+}$ current. p/4 leak subtraction pulses are not shown in voltage trace. Recording solutions: bath (1), pipette (1)

of rapid exocytotic responses. Interestingly, further enhancement of the rate of endocytosis sometimes occurred after a delay (Fig. $1 B$, response in $10 \mathrm{mM} \mathrm{Ca}^{2+}$ ). Hence, large increases in $\mathrm{Ca}^{2+}$ influx can trigger events that accelerate basal endocytosis.

\section{Exocytosis is steeply dependent on voltage-gated $\mathrm{Ca}^{2+}$ influx}

To examine the relationship between $\mathrm{Ca}^{2+}$ influx and exocytosis, we first varied the duration of the depolarizing pulse to +10 $\mathrm{mV}$. In all cells tested $(N=20)$, the amplitude of the capacitance changes increased with the duration of the depolarizing pulse (e.g., Fig. 1A). Figure $3 A$ shows the relationship between the exocytotic response and $\mathrm{Ca}^{2+}$ influx (measured as integrated $\mathrm{Ca}^{2+}$ current $\left(I_{\mathrm{Ca}}\right)$. Because the magnitude of the exocytotic response and $\mathrm{Ca}^{2+}$ current density varied from cell to cell and from culture to culture, data from each cell were normalized to value of $\Delta C_{m}\left(\Delta C_{m 100}\right)$ and integrated $\mathrm{Ca}^{2+}$ current $\left(I_{\mathrm{Ca} 100}\right)$ evoked by a $100 \mathrm{msec}$ depolarization to $+10 \mathrm{mV}\left(\Delta C_{m \mid 00}=68.5 \pm 10.4\right.$ $\mathrm{fF}, N=15$ ). The dependence of exocytosis on $\mathrm{Ca}^{2+}$ influx was fitted with

$$
\Delta C_{m} / \Delta C_{m 100}=A\left(I_{\mathrm{Ca}} / I_{\mathrm{Ca} 100}\right)^{B}
$$

with $A=1.02$ and $B=2.65$ being the best values computed with a nonlinear regression least square fit (smooth curve). To independently verify this relationship, we fixed the duration of depolarizations and varied $\mathrm{Ca}^{2+}$ influx by changing the concentration of $\mathrm{Ca}^{2+}$ in the extracellular solution between 2 and 10 mM (e.g., Fig. $1 B$ ). With this protocol, a computer fit of Equation 1 gave a value of $B=2.91$ (Fig. $3 B$ ). Hence, exocytosis by lactotrophs is steeply dependent on $\mathrm{Ca}^{2+}$ influx through voltagegated $\mathrm{Ca}^{2+}$ channels.
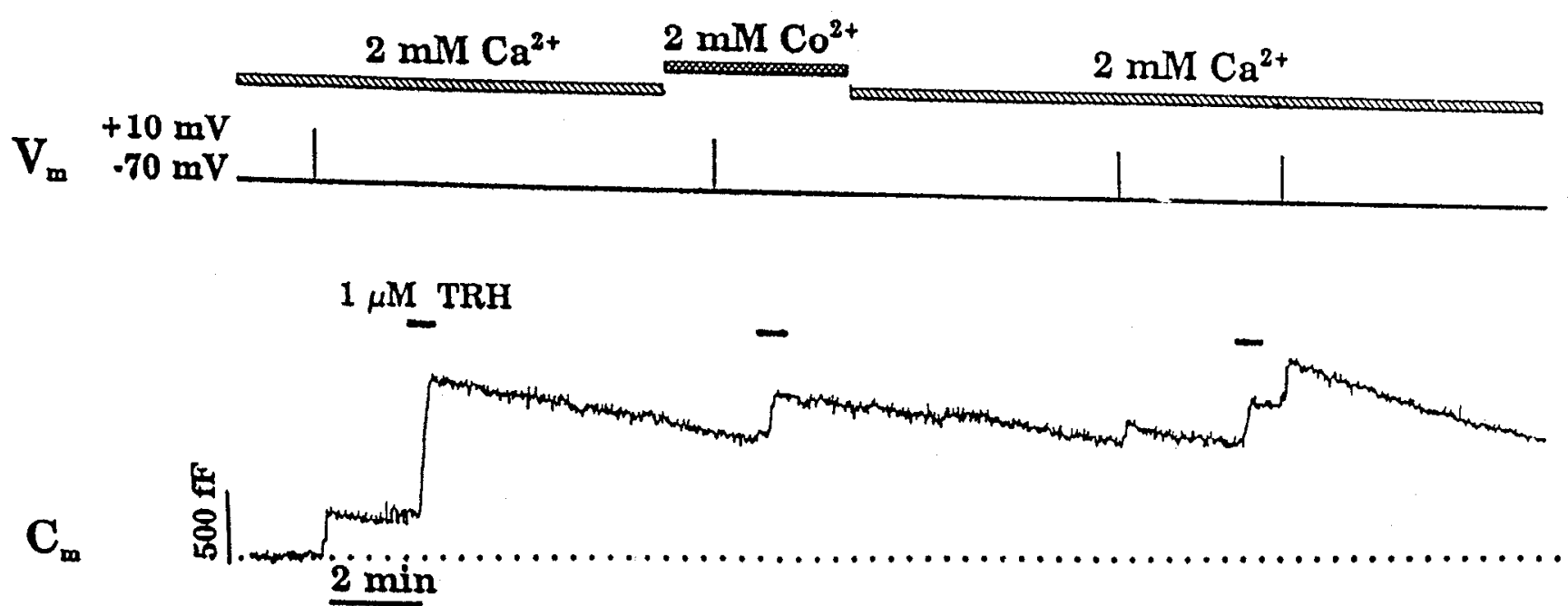

Figure 2. Depolarization-induced and TRH-induced exocytosis differ in their dependence on extracellular Ca ${ }^{2+}$. Each vertical bar in the voltage trace indicates a train of three $500 \mathrm{msec}$ depolarizations to $+10 \mathrm{mV}$ with $500 \mathrm{msec}$ interpulse repolarizations. Capacitance changes were triggered by trains of depolarizations in $\mathrm{Ca}^{2+}$ containing solution. Equimolar substitution of external $\mathrm{Ca}^{2+}$ with $\mathrm{Co}^{2+}$ completely and reversibly abolished the exocytotic response to depolarization. In contrast, application of $1 \mu \mathrm{M}$ TRH for $30 \mathrm{sec}$ induced exocytosis at $-70 \mathrm{mV}$ that was not blocked by substitution of $\mathrm{Ca}^{2+}$ with $\mathrm{Co}^{2+}$. The decrease in the amplitude of the second TRH responsc is duc to desensitization. This experiment was performed at $22^{\circ} \mathrm{C}$. Initial membrane capacitance was $8.0 \mathrm{pF}$. Recording solutions: bath (3), pipette (2). 

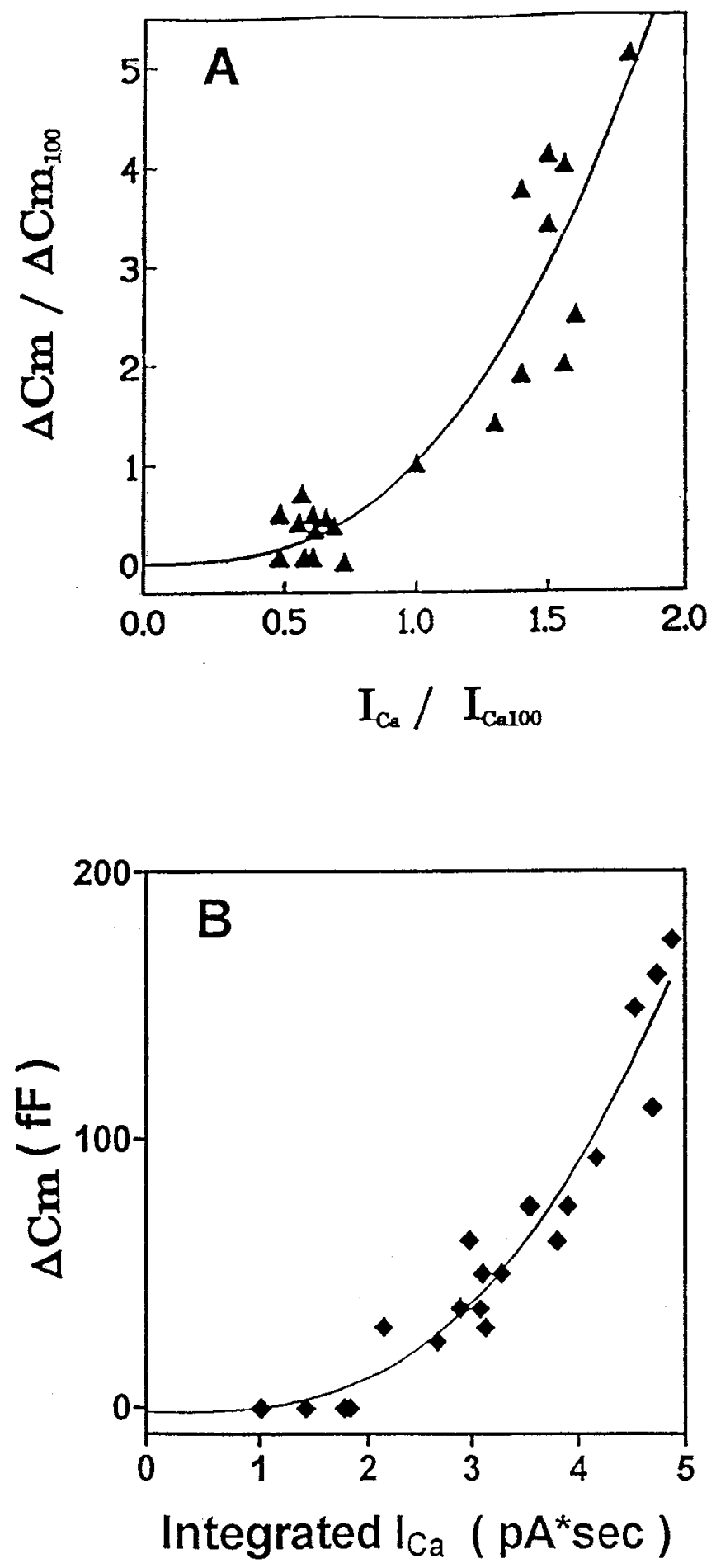

Figure 3. Dependence of $\Delta C_{m}$ on $\mathrm{Ca}^{2+}$ influx. $A, \mathrm{Ca}^{2+}$ influx was measured as integrated $\mathrm{Ca}^{2+}$ current $\left(I_{\mathrm{Ca}}\right)$. Changes in $C_{m}$ in response to depolarizations to $+10 \mathrm{mV}$ for 50,100 , and $250 \mathrm{msec}$ were measured. Data from each cell $(N=16)$ were normalized to value of $\Delta C_{m}\left(\Delta C_{m ! 00}\right)$ and integrated $\mathrm{Ca}$ current $\left(I_{\text {cal00 }}\right)$ evoked by a $100 \mathrm{msec}$ depolarization The dependence of exocytosis on $\mathrm{Ca}$ influx was fitted with Equation 1, with $A=1.02$ and $B=2.65$ being the best values computed with a nonlinear regression least square fit (smooth curve). $B, \mathrm{Ca}^{2+}$ influx was varied in a single lactotroph by changing the concentration of extracellular $\mathrm{Ca}^{2+} .2,4,6,8$, and $10 \mathrm{~mm}$ were used. Depolarizing voltages were adjusted to evoke maximal $\mathrm{Ca}^{2+}$ current. Best fit with Equation 1 was obtained with $B=2.91$. Same cell as Figure $1 B$.
TRH transiently evokes depolarization- and $\mathrm{Ca}^{2+}$-independent exocytosis

Application of $1 \mu \mathrm{M}$ TRH triggered exocytosis at $-70 \mathrm{mV}$, a voltage where voltage-gated $\mathrm{Ca}^{2+}$ channels are closed (Fig. 2). Like exocytosis evoked by depolarization, the probability of TRH-induced exocytosis at the hyperpolarized membrane potential was temperature dependent: TRH-induced exocytosis at -70 $\mathrm{mV}$ was seen in 10 of 36 cells at room temperature, but in 15 of 27 cells at $32^{\circ} \mathrm{C}$. The exocytotic response to TRH at $-70 \mathrm{mV}$ was not sustained: after 10-15 sec delay, TRH induced a 214 $\pm 34 \mathrm{fF}$ increase in $\mathrm{Cm}(N=22)$ that was complete in the next $16.7 \pm 1.8 \mathrm{sec}$ in $18 \mathrm{cells}$ and in the next $56.2 \pm 7.4 \mathrm{sec}$ in the other four cells examined. In the continued presence of TRH, exocytosis was followed by endocytosis $(-73.4 \pm 7.5 \mathrm{fF} / \mathrm{min}$, $N=31$ ) that was $\sim 40 \%$ faster than before application of the neuropeptide $(p<0.05)$. Our demonstration of $\mathrm{Ca}^{2+}$ dependent stimulation of endocytosis (see above) suggests that this could be caused by the known elevation of cytoplasmic $\mathrm{Ca}^{2+}$ produced by TRH (Malgaroli et al., 1987; Gershengorn, 1989). The exocytotic response obtained with a second exposure to TRH was always smaller than with the initial exposure. Thus, this effect of TRH partially desensitized. However, the ability to evoke multiple responses allowed us to test if TRH-evoked exocytosis required extracellular $\mathrm{Ca}^{2+}$. As can be seen in Figure 2, TRHinduced exocytosis at $-70 \mathrm{mV}$, unlike depolarization-evoked exocytosis, was not blocked by substitution of bath $\mathrm{Ca}^{2+}$ with $\mathrm{Co}^{2+}$. Therefore, at least some of the depolarization-independent exocytosis triggered by TRH occurs in the absence of extracellular $\mathrm{Ca}^{2+}$ entry through $\mathrm{Ca}^{2+}$ channels.

\section{TRH facilitates $\mathrm{Ca}^{2+}$ influx-induced exocytosis}

To investigate the possible involvement of modulation of voltage-gated $\mathrm{Ca}^{2+}$ channels in TRH-induced secretion, we studied simultaneous changes in depolarization-dependent exocytosis and $\mathrm{Ca}^{2+}$ currents during bath application of TRH. In seven of nine investigated cells TRH acted within $30 \mathrm{sec}$ to inhibit the voltage-gated $\mathrm{Ca}^{2+}$ current. During the next 4-5 min, the current gradually recovered to the control level. For example, in Figure $4, \mathrm{Ca}^{2+}$ influx was reduced by $43 \%$ after 2 min of TRH application (compare traces 1 and 2, Fig. 4C). Based on Equation 1 one would expect that depolarization-evoked exocytosis should have been reduced dramatically (i.e., by $75 \%$ ). However, depolarization-evoked exocytosis did not change substantially at this time point. Moreover, in eight of nine cells where voltage-gated $\mathrm{Ca}^{2+}$ influx was reduced or remained the same, depolarizationevoked exocytosis was enhanced (Fig. 5). This figure also illustrates that the increase in depolarization-evoked exocytosis did not necessarily have to follow large depolarization-independent exocytosis or dramatic inhibition of voltage-gated $\mathrm{Ca}^{2+}$ current. Quantitation from a series of experiments reveals that TRH application reduced average $\mathrm{Ca}^{2+}$ influx by $\sim 20 \%$ within first 30 sec (Fig. $6 A$ ) leading to a prediction that exocytosis should have been reduced to $\sim 55 \%$ of the control (Fig. $6 B$, solid bar). Yet, average depolarization-evoked exocytosis was enhanced to $\sim 150 \%$ of control (Fig. $6 B$, open bar). A plot of the relationship between $\mathrm{Ca}^{2+}$ influx and depolarization-evoked exocytosis reveals that the secretory responses to depolarization-evoked reduced $\mathrm{Ca}^{2+}$ influx in the first $3 \mathrm{~min}$ of TRH exposure were greater than predicted by Equation 1 in nearly all cases (Fig. $6 C$, open circles). This indicates that during this period induction of exocytosis by $\mathrm{Ca}^{2+}$ influx was enhanced by the neuropeptide. 
A
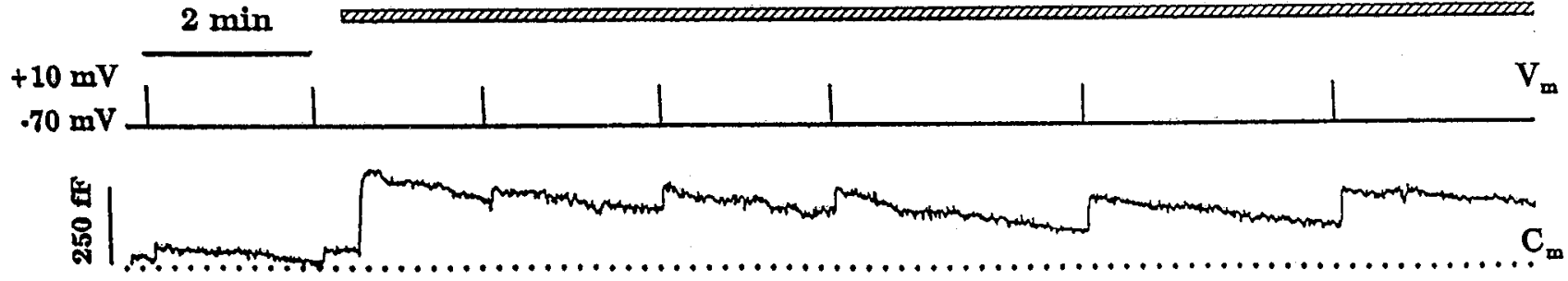

B

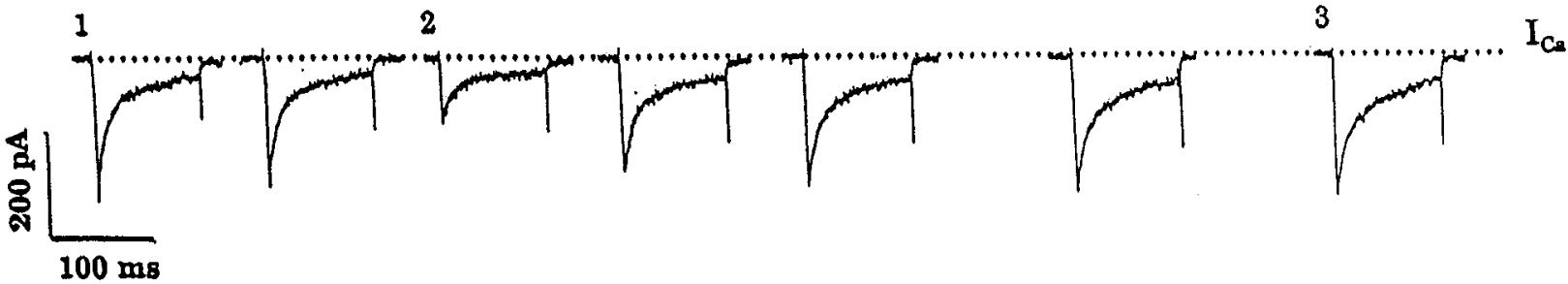

C

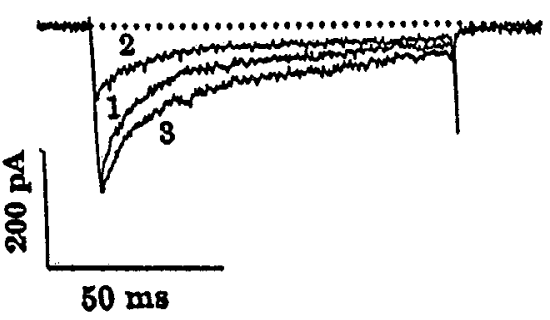

Figure 4. TRH affects exocytosis and $\mathrm{Ca}^{2+}$ currents. Vertical bars indicate single $100 \mathrm{~ms}$ depolarizations to $+10 \mathrm{mV}$ (p/4 leak subtraction pulses are not shown in voltage trace). $A, C_{m}$ changes in response to $100 \mathrm{msec}$ pulses to $+10 \mathrm{mV}$ before and after application of $1 \mu \mathrm{M}$ TRH. $B$, Corresponding $\mathrm{Ca}^{2+}$ current traces before and after TRH application (leak subtracted). $C$, Superimposed $\mathrm{Ca}^{2+}$ current traces before $(I), 1.5$ min $(2)$, and $12 \mathrm{~min}(3)$ after TRH application. Initial membrane capacitance was $7.9 \mathrm{pF}$. Recording solutions: bath (1), pipette (1).

$\mathbf{A}$

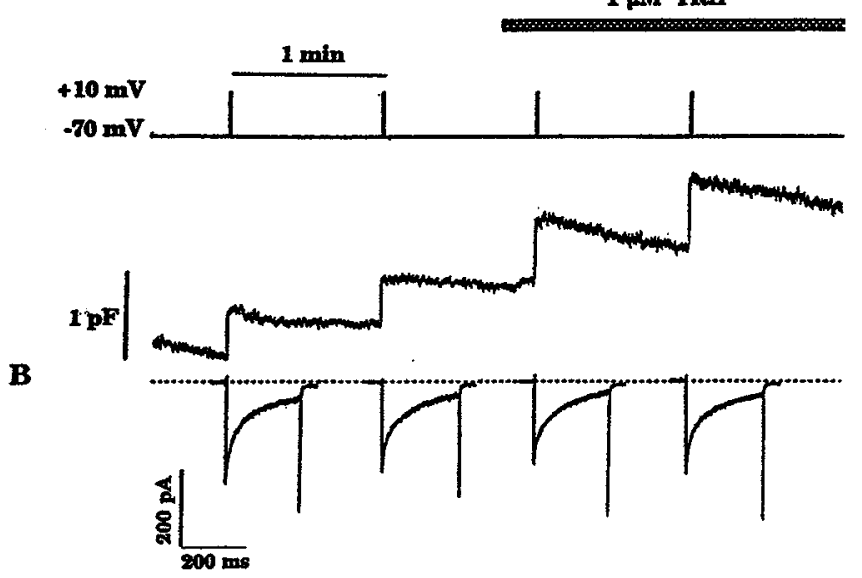

Figure 5. TRH can increase depolarization-induced exocytosis without increasing $\mathrm{Ca}^{2+}$ currents within the first minutes of application. Vertical bars indicate single $250 \mathrm{msec}$ depolarizations to $+10 \mathrm{mV}(p / 4$ leak subtraction pulses are not shown in voltage trace). $A$, Exocytotic responses are shown; $1 \mu \mathrm{M}$ 'IRH induced a small exocytotic response at $-70 \mathrm{mV}$, but significantly potentiated depolarization-evoked exocytosis. $B, \mathrm{Ca}^{2+}$ currents were not increased by TRH application. Initial membrane capacitance was $8.8 \mathrm{pF}$. Recording solutions: bath (1), pipette (1).
At later times $\mathrm{TRH}$ increases voltage-gated $\mathrm{Ca}^{2+}$ channel activity to further promote exocytosis

Following the transient decrease and recovery of voltage-gated $\mathrm{Ca}^{2+}$ current, an increase in total voltage-gated $\mathrm{Ca}^{2+}$ current was observed in the continued presence of TRH (Fig. $4 B$, traces 2 and 3). Typically, the increase in the peak current was modest when compared to control, but the apparent inactivation of current was slowed. The combination of these two effects produced an increase in total $\mathrm{Ca}^{2+}$ influx to $\sim 130 \%$ of control after $10-$ $13 \mathrm{~min}$ of TRH treatment (Fig. $6 \mathrm{~A}$ ).

The dependence of exocytosis on $\mathrm{Ca}^{2+}$ influx in untreated cells (Eq. 1) predicts that the increase in voltage-gated $\mathrm{Ca}^{2+}$ influx should increase exocytosis. If TRH along with increasing of $\mathrm{Ca}^{2+}$ influx also simultaneously increased the efficiency of coupling $\mathrm{Ca}^{2+}$ influx to exocytosis (as was seen with shorter exposures to the neuropeptide), then the depolarization-evoked increases in $\mathrm{Cm}$ seen after 4 min of TRH application should be significantly larger than predicted by Equation 1 . However, as can be seen in Figure $6, B$ and $C$, the dependence of the exocytosis on $\mathrm{Ca}^{2+}$ influx was well predicted by Equation 1 after 4 min of TRH application. This finding suggests that the enhanced coupling of $\mathrm{Ca}^{2+}$ influx to exocytosis is marked for the first 3 


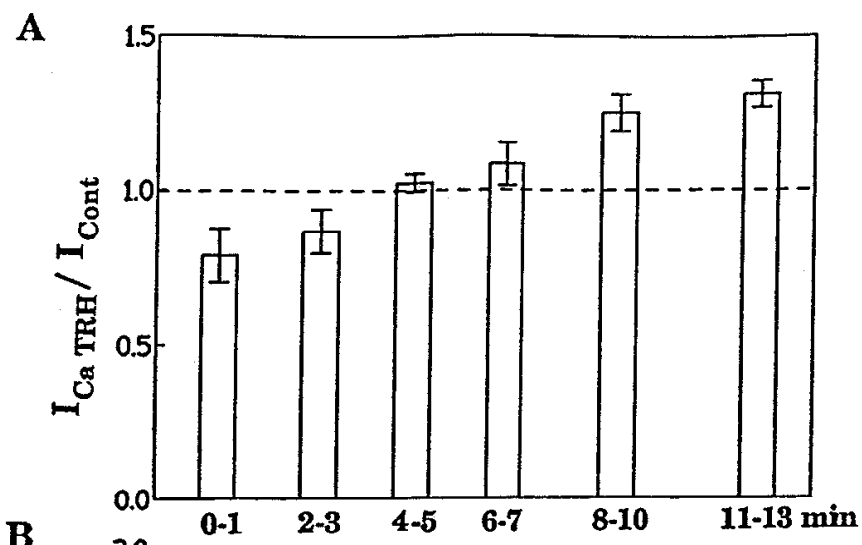

$\mathbf{B}$

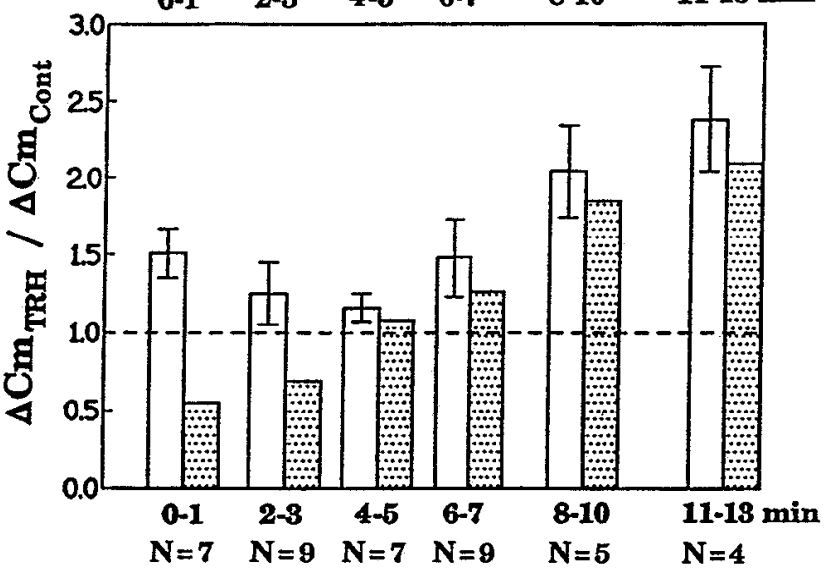

$\mathbf{C}$

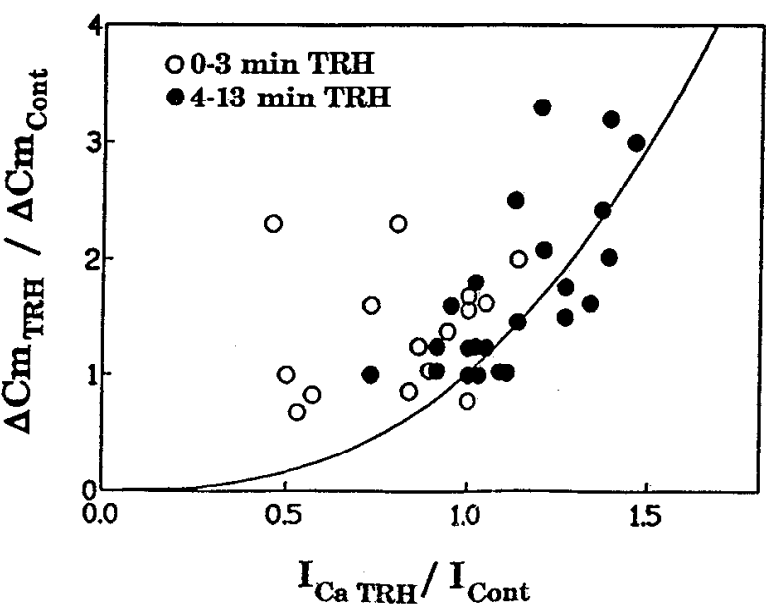

Figure 6. Changes in depolarization-evoked $\mathrm{Ca}^{2+}$ influx and exocytosis during continuous application of $1 \mu \mathrm{M}$ TRH. $A$, Time course of the changes in depolarization-evoked $\mathrm{Ca}^{2+}$ influx (presented as integrated current normalized to control). Note that TRH has a biphasic effect on depolarization-evoked $\mathrm{Ca}^{2+}$ influx. $B$, Exocytotic responses were measured and normalized to responses before TRH application (open bars) and predicted from Equation 1 (hatched bars). Note that while Equation 1 predicts that TRH should have initially decreased depolarization-evoked exocytosis, exocytotic responses increased. At later times, exocytotic responses are similar to predictions of Equation 1. $C$, Scatter plot showing the effect of TRH on the dependence of exocytosis $\left(\Delta C_{m}\right)$ on $\mathrm{Ca}^{2+}$ influx. Each point represents an individual depolarization-evoked exocytotic response after superfusion with TRH. Values are normalized to responses from the same cell before application of the neuropeptide. The smooth curve is identical to the curve shown in Figure 3A. Open circles show responses within the first $3 \mathrm{~min}$ of TRH application. Note only one of these points is below the curve. Solid circles show responses evoked after TRH had been applied for 4-14 min. Note that these points appear to be distributed along the standard curve. min of TRH application. Then, as that effect subsides, depolarization-evoked exocytosis is promoted by increasing voltagegated $\mathrm{Ca}^{2+}$ channel activity.

\section{TRH modulates high-voltage-activated $\mathrm{Ca}^{2+}$ channels}

HVA (high-voltage-activated) and LVA (low-voltage-activated) $\mathrm{Ca}^{2+}$ channel currents in lactotrophs can be most reliably separated with the use of $\mathrm{Ba}^{2+}$ as a charge carrier (DeRiemer and Sakmann, 1986; Lingle et al., 1986; Cobbett et al., 1987; Lewis et al., 1988). Therefore, we examined TRH action on voltagegated $\mathrm{Ba}^{2+}$ currents. Superfusion with $1 \mu \mathrm{M}$ TRH first acted within $10 \mathrm{sec}$ to inhibit maximal voltage-gated $\mathrm{Ba}^{2+}$ current elicited from holding potential $-70 \mathrm{mV}$ by $\sim 20 \%$ on average (Fig. $7 A$ ). The current amplitude then gradually increased so that it reached the initial level after 4 min of superfusion with TRH, and a level of $20 \%$ higher than the initial control value (i.e., before TRH application) after $10 \mathrm{~min}$ of neuropeptide application. TRH inhibition and stimulation of channel activity did not alter current kinetics (Fig. 7B), which showed little inactivation, suggesting that the neuropeptide does not affect the voltagedependent activation and inactivation of the channels. Most imporlantly, these experiments demonstrate that the sequential opposing effects of TRH on voltage-gated $\mathrm{Ca}^{2+}$ channels occur regardless of whether $\mathrm{Ca}^{2+}$ or $\mathrm{Ba}^{2+}$ is used as the charge carrier.

$\mathrm{Ba}^{2+}$ currents were then evoked from a holding potential of $-40 \mathrm{mV}$ to isolate HVA currents and subtracted from the total current evoked from $-70 \mathrm{mV}$ to estimate the amplitude of the LVA currents. As can be seen in Figure $7 C$, prolonged TRH application increased the magnitude of the HVA current without altering LVA currents. No change in HVA current kinetics was produced by TRH (data not shown) suggesting that the apparent kinetic changes in the $\mathrm{Ca}^{2+}$ currents described above (Fig. 4) were probably due to the selective increase in the HVA component of the total current. In separate experiments where the holding potential was maintained at $-40 \mathrm{mV}$, we found that HVA current was transiently inhibited and then later stimulated by TRH (data not shown). Thus, TRH modulates $\mathrm{HVA} \mathrm{Ca}^{2+}$ channel activity.

\section{Activation of protein kinase $C$ can account for the third effect of $T R H$}

To test if PKC could mediate one or more of the three TRH actions, we superfused patch clamped lactotrophs with TPA (12$O$-tetradecanoylphorbol 13-acetate), a phorbol ester activator of PKC, or its inactive stereoisomer $4 \alpha$-TPA. We found that neither TPA nor $4 \alpha$-TPA affected exocytosis in cells voltage clamped at $-70 \mathrm{mV}(N=32)$. However, $100-500 \mathrm{~nm}$ TPA acted over a period of 3-4 min to increase depolarization-evoked exocytosis in 17 of 28 cells (Fig. 8A). In contrast, equivalent doses of $4 \alpha-$ TPA did not produce a significant effect $(N=6)$. Simultaneous measurements of voltage-gated $\mathrm{Ca}^{2+}$ currents and exocytosis indicated that $100 \mathrm{nM}$ TPA facilitated depolarization-evoked exocytosis to $220 \pm 38 \%$ of control while increasing $\mathrm{Ca}^{2+}$ influx to $151 \pm 27 \%$ of control $(N=4)$ (Fig. $8 B$ ). Since exocytotic responses were not greater than predicted by Equation 1, the efficiency of coupling $\mathrm{Ca}^{2+}$ influx to exocytosis was not increased. Rather, PKC facilitated exocytosis by stimulating voltage-gated $\mathrm{Ca}^{2+}$ channel activity. This finding indicates that activation of PKC alone does not mimic the first two TRH effects. Instead, activation of PKC appears to be sufficient to produce the third phase of TRH action. 
$\mathbf{A}$

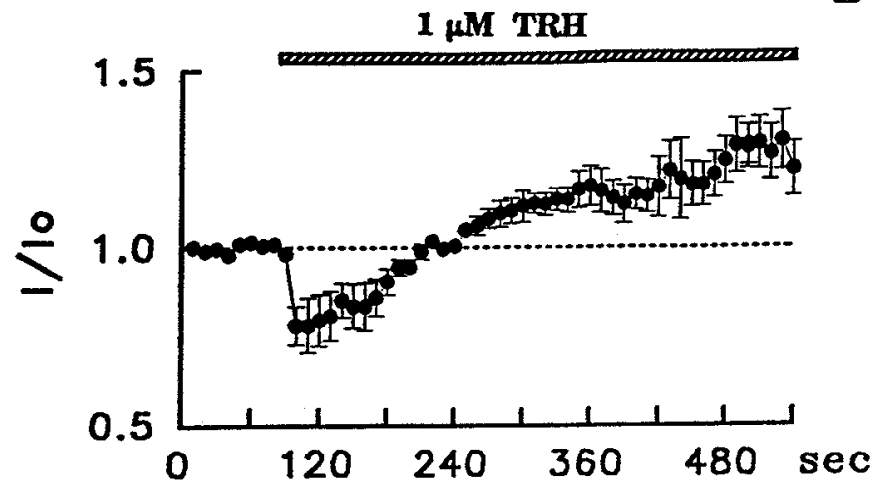

B

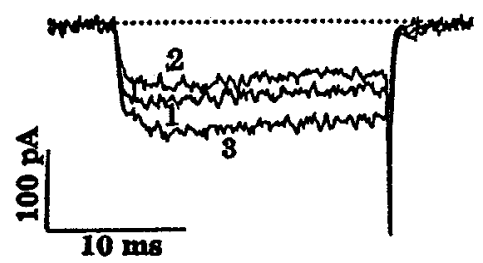

C

Total

HVA

LVA

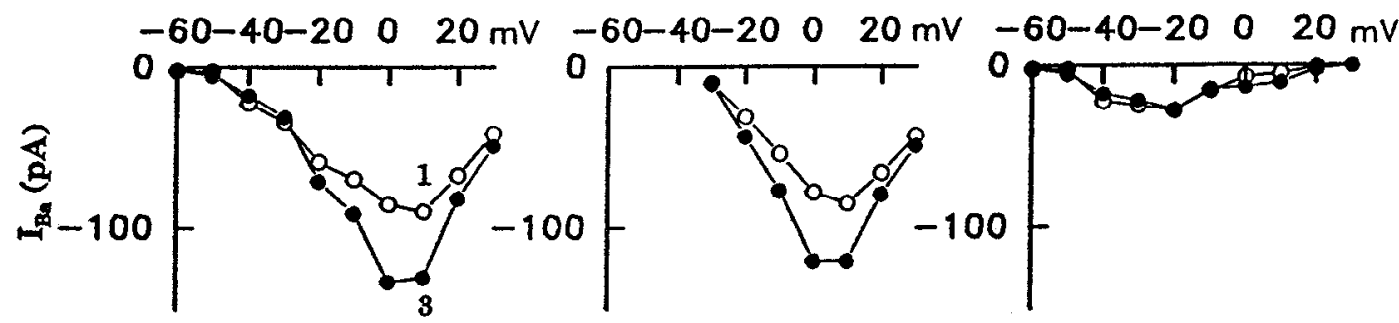

Figure 7. TRH modulates high-voltage-activated $(H V A) \mathrm{Ca}^{2+}$ channels. $A$, Time course of modulation of peak voltage-gated $\mathrm{Ba}^{2+}$ current by 1 $\mu \mathrm{M}$ TRH. Currents were evoked by depolarizations from $-70 \mathrm{mV}$ to $+10 \mathrm{mV}$. Each point is average from six cells. $B$, Representative current traces showing $I_{\mathrm{Ba}}$ before (1), $10 \mathrm{sec}$ after (2), and $8 \mathrm{~min}$ after (3) superfusion with TRH. $C$, Representative current-voltage relationships for total $I_{\mathrm{Ba}}$ (left), high-voltage-activated (HVA) current (middle), and low-voltage-activated (LVA) currents (right) before (open circles) and 8 min after (solid circles) superfusion with TRH. HVA currents were recorded from holding potential $-40 \mathrm{mV}$. LVA currents were obtained by subtracting HVA current traces from total current traces. Data is from same cell shown in $B$, Recording solutions: bath (2), pipette (1).

\section{Discussion}

Exocytosis by a peptidergic cell is steeply dependent on $\mathrm{Ca}^{2+}$ influx through voltage-gated $\mathrm{Ca}^{2+}$ channels

It was known that brief depolarizations (i.e., $<250 \mathrm{msec}$ ) trigger exocytosis, presumably reflecting peptide secretion, by neurohypophysis terminals (Lim et al., 1990), intermediate lobe melanotrophs (Thomas et al., 1990), and pancreatic $\beta$ cells (AmInala et al., 1993a,b). However, previous experiments performed with conventional whole cell recording demonstrated that it was very difficult to trigger exocytosis with voltage-clamp depolarization of bovine lactotrophs (Mason et al., 1989) and rat gonadotrophs (Tse et al., 1993). Those latter results suggested that action potentials might play a minor role in evoking peptide secretion by anterior pituitary cells. However, we found that 50 $250 \mathrm{msec}$ voltage-clamp depolarizations could effectively trigger exocytosis from rat lactotrophs. Since it is known that exocytotic responses to depolarization wash out with wholc cell recording (Augustine and Neher, 1992; Ammala et al., 1993b), it is possible that the use of the perforated patch-clamp configuration and performing experiments at $32^{\circ} \mathrm{C}$ were essential for detecting depolarization-evoked exocytosis. Therefore, under physiological conditions $\mathrm{Ca}^{2+}$ influx through voltage-gated $\mathrm{Ca}^{2+}$ channels may effectively trigger peptide secretion from some anterior pituitary cells.

Our experiments revealed that increasing $\mathrm{Ca}^{2+}$ influx through voltage-gated $\mathrm{Ca}^{2+}$ channels by lengthening the duration of depolarization or by increasing bath $\mathrm{Ca}^{2+}$ dramatically increased exocytosis: exocytotic responses are proportional to $\mathrm{Ca}^{2+}$ influx raised to the third power. This finding is reminiscent of the previously described cooperative relationship between the rate of exocytosis and cytoplasmic $\mathrm{Ca}^{2+}$ concentration in chromaffin cells (Augustine and Neher, 1992) and melanotrophs (Thomas et al., 1990). Likewise, in the squid giant synapse, transmission is cooperatively dependent on $\mathrm{Ca}^{2+}$ influx with voltage clamp depolarizations $>5 \mathrm{msec}$ in duration (Augustine et al., 1985). Perforated patch-clamp recordings reveal that lactotroph action potential duration is long $(>10 \mathrm{msec})$ and can vary in response to modulators (data not shown). The steep dependence of exocytosis on $\mathrm{Ca}^{2+}$ influx suggests that even subtle changes in action potential activity might affect prolactin secretion. This may be a general feature of regulation of peptide secretion by neuroendocrine cells (Bondy et al., 1986; Gainer et al., 1987).

\section{Three phases of TRH-induced facilitation of exocytosis}

Our finding that TRH produces three temporally distinct effects to promote exocytosis is unprecedented. Previous work with pituitary tumor cells had suggested that TRH induces two phases of prolactin secretion: a transient burst associated with intracellular $\mathrm{Ca}^{2+}$ release and a plateau phase that requires extracellular $\mathrm{Ca}^{2+}$ influx (Gershengorn, 1989). Electrophysiological studies had suggested that the plateau phase is due to increased action potential activity (Mason et al., 1988, 1989; Iijima et al., 1990). It is likely that the transient depolarization- and extracellular calcium-independent exocytosis triggered by TRH (e.g., Figs. 2, 


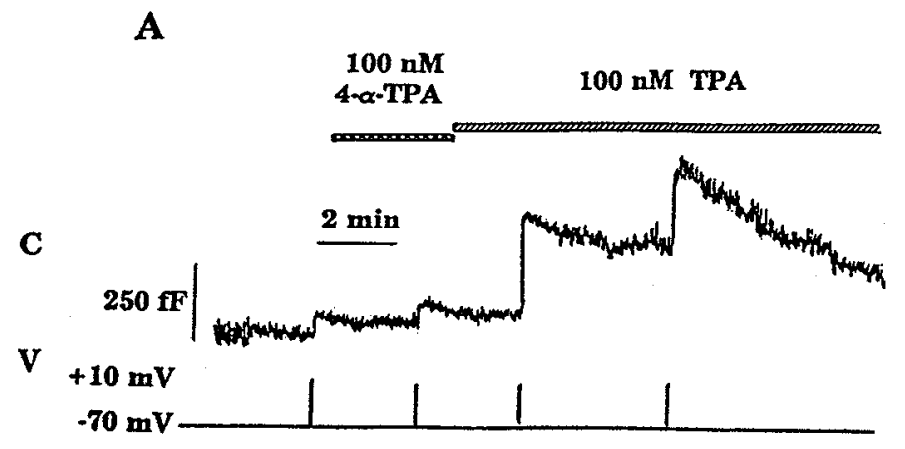

B

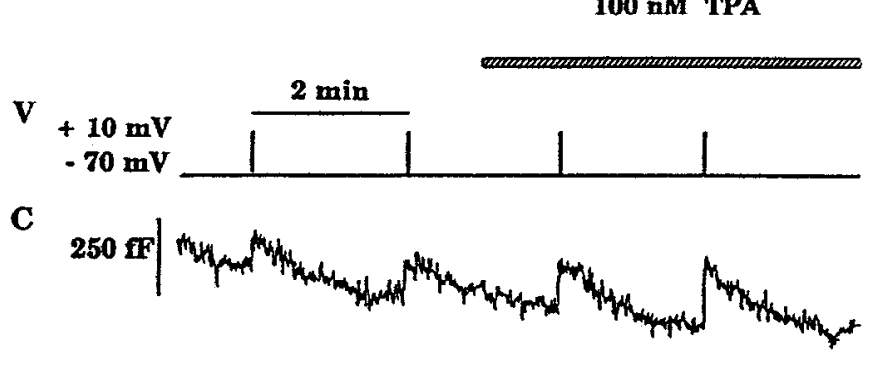

I
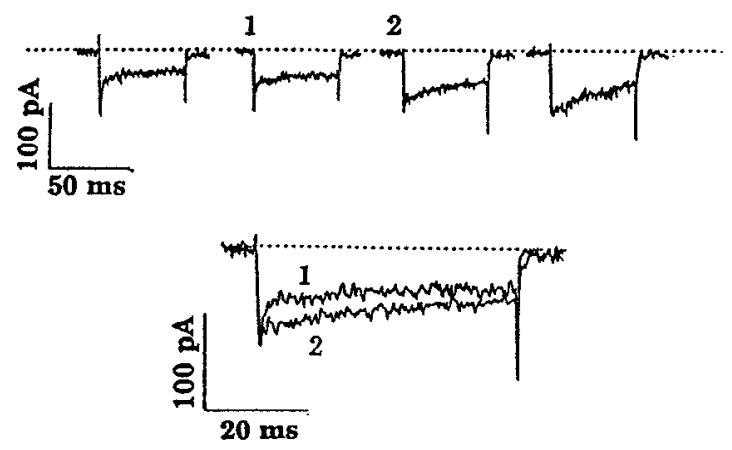

Figure 8. Activation of protein kinase $\mathrm{C}$ increases depolarizationevoked exocytosis and voltage-gated $\mathrm{Ca}^{2+}$ current. $A$, Facilitation of exocytotic responses by $100 \mathrm{nM}$ TPA, a PKC activator. $4-\alpha$-TPA does not produce this effect. Recording solutions: bath (3), pipette (2). $B$, $100 \mathrm{nM}$ TPA increases depolarization-evoked exocytosis and voltagegated $\mathrm{Ca}^{2+}$ current. $p / 4$ leak subtraction pulses are not shown in voltage trace. Recording solutions: bath (1), pipette (1).

4) is evoked by the brief (i.e., $<1 \mathrm{~min}$ ) release of intracellular $\mathrm{Ca}^{2+}$ seen in normal rat lactotrophs at $32^{\circ} \mathrm{C}$ (Malgaroli et al., 1987). However, if the plateau phase was only caused by increased action potential firing, then we would not have expected to detect TRH modulation of exocytosis evoked by voltageclamp depolarizations. Thus, our finding that TRH facilitates depolarization-evoked exocytosis was not anticipated from previous work with the neuropeptide.

Interestingly, two phases of facilitation of depolarizationevoked exocytosis were induced by the neuropeptide. During the first few minutes, TRH enhanced exocytosis while inhibiting $\mathrm{Ca}^{2+}$ influx through voltage-gated $\mathrm{Ca}^{2+}$ channels. This early action might account for the contribution of voltage-gated $\mathrm{Ca}^{2+}$ channels to the initial 2-5 min burst of TRH-induced prolactin secretion by normal lactotrophs described previously (Sato et al., 1992). At later times, exocytosis was augmented by increasing voltage-gated $\mathrm{Ca}^{2+}$ channel current. This effect could participate in producing the plateau phase of secretion.

It is established that TRH stimulates PKC and that activation of this enzyme increases prolactin secretion (Negro-Vilar and Lapetina, 1985; Gershengorn, 1989). Therefore, we tested whether the activation of PKC alone could account for any of the three facilitatory effects of the neuropeptide. Work with pituitary tumor cells suggested that PKC sensitizes the secretory apparatus to increase basal and $\mathrm{Ca}^{2+}$ influx-dependent prolactin secretion (Ronning and Martin, 1986; Haymes and Hinkle, 1993), but does not stimulate $\mathrm{Ca}^{2+}$ channels (Kramer et al., 1991). However, in normal lactotrophs phorbol ester activation of PKC increased exocytotic responses to depolarization by stimulating voltage-gated $\mathrm{Ca}^{2+}$ channels. Furthermore, PKC did not induce exocytosis at a hyperpolarized membrane potential. Thus, PKC may act via different mechanisms to stimulate secretion by normal and clonal pituitary cells. In addition, our work provides direct evidence that PKC modulation of $\mathrm{Ca}^{2+}$ channels can facilitate secretion. Finally, it is apparent that PKC activation can only account for the third phase of TRH action in normal lactotrophs.

The limited action of PKC suggests that the second phase of facilitation of depolarization-evoked exocytosis requires a different signal transduction mechanism (possibly in conjunction with PKC). There are several messengers that might facilitate depolarization-evoked exocytosis without stimulating voltagegated $\mathrm{Ca}^{21}$ channels. TRH activates novel $\mathrm{G}$ protein and tyrosine kinase pathways (Bauer et al., 1994; Brady et al., 1994; Ohmichi et al., 1994). In addition, release of intracellular $\mathrm{Ca}^{2+}$ may be involved: an increase in baseline $\left[\mathrm{Ca}^{2+}\right]_{i}$ could sum with $\mathrm{Ca}^{2+}$ influx through voltage-gated channels to trigger exocytosis. However, this latter hypothesis is called into question by the fact that $\mathrm{Ca}^{2+}$ release in rat lactotrophs at $32^{\circ} \mathrm{C}$ is too brief $(\sim 1 \mathrm{~min}$; Malgaroli et al., 1987) to account for the second phase of TRH action. A plausible alternative is that transient $\mathrm{Ca}^{2+}$ release produces a sustaincd increase in the coupling cfficacy of between $\mathrm{Ca}^{2+}$ influx and exocytosis (von Ruden and Neher, 1993). Testing this mechanism is difficult because blockers of TRH-induced intracellular $\mathrm{Ca}^{2+}$ release affect basal $\mathrm{Ca}^{2+}$ concentration, $\mathrm{Ca}^{2+}$ channel activity, and prolactin secretion (Kramer et al., 1991; Sato et al., 1992). Thus, extensive studies with intracellular $\mathrm{Ca}^{2+}$ measurements and a variety of pharmacological agents will be required to fully analyze all of the possible mechanisms underlying the second phase of TRH action. Nevertheless, our studies suggest that the ability of this neuromodulator to activate multiple second messenger systems provides the basis for producing temporally distinct effects on exocytosis.

\section{Modulation of voltage-gated $\mathrm{Ca}^{2+}$ channel currents and exocytotic secretion}

This report constitutes the first demonstration that $\mathrm{TRH}$ regulates lactotroph voltage-gated $\mathrm{Ca}^{2+}$ channels and exocytotic activity. There are few other preparations where modulation of $\mathrm{Ca}^{2+}$ channels and exocytosis have been followed simultaneously (Ammala et al., 1993a; Artalejo et al., 1994). In the absence of direct measurements, most investigators have assumed that secretion is proportional to $\mathrm{Ca}^{2+}$ influx. Our results indicate that this is not always the case. During the first few minutes of TRH application, depolarization-evoked exocytosis is enhanced despite the fact that voltage-gated $\mathrm{Ca}^{2+}$ channels are inhibited by the neuropeptide. Thus, $\mathrm{Ca}^{2+}$ current measurements alone do not predict exocytosis because induction of exocytosis by $\mathrm{Ca}^{2+}$ in- 
flux can be augmented by the neuropeptide. In contrast, after 8 min of TRH exposure, voltage-gated $\mathrm{Ca}^{2+}$ current is increased. Since the relationship between $\mathrm{Ca}^{2+}$ influx and exocytosis is not altered during this period, we conclude that the modulation of these channels is sufficient to explain the observed increase in depolarization-evoked exocytosis. Thus, the ability to predict the impact of modulating $\mathrm{Ca}^{2+}$ influx on peptide secretion may depend on the duration of neuropeptide exposure.

Rat lactotrophs express two types of voltage-gated $\mathrm{Ca}^{2+}$ channels: high-voltage-activated (HVA) and low-voltage-activated (LVA) channels (DeRjemer and Sakmann, 1986; Lingle et al., 1986; Cobbett et al., 1987; Lewis et al., 1988). We found that TRH produces a biphasic effect on lactotroph $\mathrm{HVA} \mathrm{Ca}^{2+}$ current. However, LVA current was not increased by the neuropeptide. It is likely that most of the LVA current is inactivated with physiological action potential activity (Cobbett et al., 1987). Hence, modulating HVA channels may be an efficient mechanism for altering $\mathrm{Ca}^{2+}$ influx into lactotrophs.

\section{TRH modulation of peptide secretion and synaptic transmission}

TRH stimulates secretion of prolactin and TSH by anterior pituitary cells and catecholamines by some CNS neurons (Faglia and Persani, 1991). In addition, TRH augments long-term potentiation in the hippocampus (Ishihara et al., 1991, 1992). Since the same TRH receptor is expressed in the brain and in the anterior pituitary (Wu et al., 1992; Satoh et al., 1993), we suggest that TRH might employ similar mechanisms to facilitate secretion by neurons and lactotrophs. It is possible that each phase of TRH action may differentially depend on the dose and the duration of exposure to the neuropeptide. Furthermore, each facilitating mechanism might be differentially affected by other transmitters. This may be a crucial feature in the central nervous system and in the antcrior pituitary where secretion sites can be simultaneously exposed to a variety of interacting neurotransmitters. Therefore, the use of temporally distinct regulatory mechanisms might facilitate intricate control of secretion by neuromodulators.

\section{References}

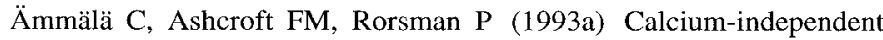
potentiation of insulin release by cyclic AMP in single beta-cells. Nature 363:356-358.

Ämmïlä C, Eliasson L, Bokvist K, Larsson O, Asheroft FM, Rorsman P (1993b) Exocytosis elicited by action potentials voltage-clamp calcium currents in individual mouse pancreatic B-cells. J Physiol (Lond) 472:665-688.

Artalejo CR, Adams ME, Fox A (1994) Three types of $\mathrm{Ca}^{2+}$ channel trigger secretion with different efficacies in chromaffin cells. Nature 367:72-76

Augustine GJ, Neher E (1992) Calcium requirements for secretion in hovine chromaffin cells. J Physiol (Lond) 450:247-271

Augustine GJ, Charlton MP, Smith SJ (1985) Calcium entry and transmitter release at voltage-clamped nerve terminals of squid. J Physiol (Lond) 369:163-181.

Bauer CK, Davison I, Kubasov I, Schwarz JR, Mason WT (1994) Different $G$ proteins are involved in the biphasic response of clonal rat pituitary cells to thyrotropin-releasing hormone. Pfluegers Arch 428: $17-25$.

Bondy CA, Gainer H, Russell JT (1987) Effects of stimulus frequency and potassium channel blockade on the secretion of vasopressin and oxytocin from the neurohypophysis. Neuroendocrinology 46:258267

Brady KD, Han B, Tashjian AH (1994) Kinetics and reversibility of thyrotropin-releasing hormone-stimulated guanine nucleotide exchange in membranes from $\mathrm{GH}_{4} \mathrm{C}_{1}$ cell. Mol Pharmacol 46:644-652.

Cobbett P, Ingram CD, Mason WT (1987) Voltage-activated currents through calcium channels in normal bovine lactotrophs. Neuroscience 23:661-677.

DeRiemer SA, Sakmann B (1986) Two calcium currents in normal rat anterior pituitary cells identified by a plaque assay. Exp Brain Res 14:139-164.

Faglia G, Persani L (1991) Thyrotropin-releasing hormone. Basic and clinical aspects. In: Brain endocrinology (Motta M, ed), pp 315-350. New York: Raven.

Gainer H, Wolfe SA, Obaid AL, Salzberg BM (1986) Action potentials and frequency-dependent secretion in the mouse neurohypophysis. Neuroendocrinology 43:557-563.

Gershengorn MC (1989) Role of inositol lipid second messengers in regulation of secretion: studies of thyrotropin-releasing hormone action in pituitary cells. In: Secretion and its control (Oxford GS, Armstrong CM, eds), pp 1-15. New York: Rockefeller UP.

Haymes AA, Hinkle PM (1993) Activation of protein kinase C increases $\mathrm{Ca}^{2+}$ sensitivity of secretory response of GH3 pituitary cells. Am J Physiol 264:C1020-1028.

Iijima T, Sand O, Sekiguchi T, Matsumoto G (1990) Simultaneous recordings of cytosolic $\mathrm{Ca}^{2+}$ level and membrane potential and current during the response to thyroliberin in clonal rat anterior pituitary cells. Acta Physiol Scand 140:269-278.

Ishihara K, Katsuki H, Kawabata A, Sasa M, Satoh M, Takaory S (1991) Effects of thyrotropin-releasing hormone and a related analog, CNK-602A, on long-term potentiation in the mossy fiber-CA3 pathway of guinea pig hippocampal slices. Brain Res 554:203-208.

Ishihara K, Katsuki H, Sugimura M, Satoh M (1992) YM-14673, a new thyrotropin-releasing hormone analog, augments long-term potentiation in the mossy fiber-CA3 system of guinea pig hippocampal slices. J Pharmacodynamics 15:75-78.

Kramer RH, Kaczmarek LK, Levitan ES (1991) Neuropeptide inhibition of voltage-gated $\mathrm{Ca}^{2+}$ channels mediated by mohilization of intracellular $\mathrm{Ca}^{2+}$. Neuron 6:557-563.

Lewis DL, Goodman MB, St John PA, Barker GL (1988) Calcium currents and Fura-2 signals in fluoresecnec-activated cell sorted lactotrophs and somatotrophs of rat anterior pituitary. Endocrinology 123:661-621

Lim NH, Nowycky M, Bookman RJ (1990) Direct measurement of exocytosis and calcium currents in single isolated nerve terminals. Nature 344:449-451.

Lindau M, Neher E (1988) Patch-clamp techniques for time-resolved capacitance measurements in single cells. Pfluegers Arch 411:137 146

Lingle CJ, Sombati S, Freeman ME (1986) Membrane currents in identified lactotrophs of rat anterior pituitary. J Neurosci 6:2995-3005.

Malgaroli A, Vallar L, Elahi FR, Pozzan T, Spada A, Meldosesi J (1987) Dopamine inhibits cytosolic $\mathrm{Ca}^{2+}$ increases in rat lactotroph cells. J Biol Chem 262:13920-13927.

Mason WT, Rawlings SR, Cobbet P, Sikdar SK, Zorec SN, Akerman SN, Benham CD, Berridge MJ, Cheek T, Moreton RB (1988) Control of secretion in anterior pituitary cells-linking ion channels, messengers and exocytosis. J Exp Biol 139:287-316.

Mason WT, Sikdar SK, Zorec R, Akerman S, Rawlings SR, Cheek T, Moreton R, Berridge M (1989) Ion channels, Intracellular calcium, and exocytosis: control of hormone secretion in cultured bovine pituitary lactotrophs. In: Secretion and its control (Oxford GS, Armstrong CM, eds), pp 226-238. New York: Rockefeller UP.

Negro-Vilar A, Lapetina EG (1985) 1,2-Didecanoylglycerol and phorbol 12,13-dibutyrate enhance anterior pituitary hormone secretion in vitro. Endocrinology 117:1559-1564.

Ohmichi M, Sawada T, Kanda Y, Koike K, Hirota K, Miyake A, Saltiel AR (1994) Thyrotropin-releasing hormone stimulates MAP kinase activity in GH3 cells by divergent pathways. J Biol Chem 269:37833788.

Okano K, Monk JR, Fernandez J (1993) GTP $\gamma$ S stimulates exocytosis in patch-clamped melanotrophs. Neuron 11:165-172.

Rae J, Cooper K, Gates G, Watsky M (1991) Low access resistance perforated patch recordings using amphotericin B. J Neurosci Methods 37:15-26.

Ronning SA, Martin TF (1986) Characterization of phorbol ester- and diacylglycerol-stimulated secretion in permeable $\mathrm{GH}_{3}$ pituitary cells. Interaction with $\mathrm{Ca}^{2+}$. J Biol Chem 265:7623-7631.

Sato N, Wang X, Greer MA (1992) An acute release of Ca2 + from sequestered intracellular pools is not the primary transduction mech- 
anism causing the initial burst of PRL and TSH secretion induced by TRH in normal rat pituitary cells. Cell Calcium 13:173-182.

Satoh T, Feng P, Kim UJ, Wilber JF (1993). Identification of thyrotropin-releasing hormone receptor messenger RNA in the rat central nervous system and eye. Mol Brain Res 19:175-178.

Sikdar SK, Zorec R, Brown D, Mason WT (1989) Dual effects of G-protein activation on calcium-dependent exocytosis in bovine lactotrophs. FEBS Lett 253:88-92.

Sikdar SK, Zorec R, Mason WT (1990) cAMP directly facilitates calcium-induced exocytosis in bovine lactotrophs. FEBS Lett 273:150 154.

St John PA, Dufy-Barbe L, Barker J (1986) Anti prolactin cell-surface immunoreactivity identifies a subpopulation of lactotrophs from the rat anterior pituitary. Endocrinology 119:2783-2795.
Thomas P, Surprenant A, Almers W (1990) Cytosolic $\mathrm{Ca}^{2+}$, exocytosis, and endocytosis in single melanotrophs of the rat pituitary. Neuron 5:723-733.

Tse A, Tse FW, Almers W, Hille B (1993) Rhythmic exocytosis stimulated by $\mathrm{GnRH}$-induced calcium oscillations in rat gonadotropes. Science 260:82-84.

von Ruden L, Neher E (1993) A Ca-dependent early step in the release of catecholamines from adrenal chromaffin cells. Science 262:10611065.

Wu W, Elde R, Wessendorf MW, Hökfelt T (1992) Identification of neurones expressing thyrotropin-releasing hormone receptor mRNA in spinal cord lower brainstem of rat. Neurosci Lett 142:143-146.

Zorec R, Sikdar SK, Mason WT (1991) Increased cytosolic calcium stimulates exocytosis in bovine lactotrophs. J Gen Physiol 97:473497. 